日平滑笳誌（Jap. J. Smooth Muscle Res.） 14：55-65, 1978.

\title{
合成モチリンの胃運動作用について
}

\author{
秋田大学医学部 第一外科学教室 \\ 谷充 \\ 琵琶湖霄腸病院 \\ 菅 原 俠 治, 加 藤 守 彦 \\ 社会保険神戸中央病院 \\ 真 部 光 正 \\ 京都府立医科大学 公衆衛生学教室 \\ 赤坂 裕三, 川 井啓 市
}

\section{EFFECT OF SYNTHETIC MOTILIN ON GASTRIC MOTILITY}

Mitsuru TANI

1st Department of Surgery, School of Medicine, Akita University, Akita.

Kyoji Sugawara and Moihiko Katoh

Biwako GI Hosptial, Otsu.

Mitsumasa Manabe

Shakaihoken Kobe Chuo Hosptial, Kobe.

Yuzo Akasaka Keiichi KawaI

School of Preventive Medicine, Kyoto Prefectural University of Medicine, Kyoto.

The effects of the synthetic motilin on the gastric motility were investigated in the dogs with innervated antral pouches in fasting state.

The results were as follows:

1) The synthetic motilin stimulated markedly the gastric motor activity in both the contraction pressure and the frequency of the peristalsis.

2) Tetragastrin produced more regular and higher frequent contractions compared with synthetic motilin, but acted to weaker the contraction pressure.

3) In simultaneous administration of the synthetic motilin and the tetragastrin, the synthetic motilin acted more strongly in the contraction pressure, on the other hand tetragastrin in the frequency of the peristalsis.

4) The peristaltic contractions induced by synthetic motilin were completely abolished by the administration of the atropine sulfate.

5) Under medical vagotomy, synthetic motilin was not able to produce any peristatlic contractions, but tetragastrin stimulated strongly the gastric motility.

緒

1905 年に Edkins によって発見された消化管ホ

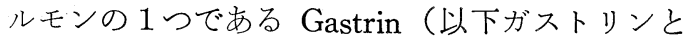
記す）は，胃液の分泌ならびに胃運動作用に極め
言

て重要な働きを有しておりり，今日臨床上とりわ け消化性潰瘍の成因ならびに治療上無視すること の出来ないものとなっている.ガストリンは, の 
ちに Gregory \& Tracy（1964）によって合成され るに至った．ところが，ガストリンの発見にひき つづき, 1972 年には, Brownら（1967）によって, Motilin（以下モチリンと記す）なるホルモンが十 二指腸から産生されることが発見され, さらに合 成されるに至った（Yojima, Kai and Shimizu). モチリンは，胃の運動を刺激する点ではガストリ ンと同様であるが，その作用が，主として空腹時

\section{実験}

実験動物には, 体重約 $10 \sim 15 \mathrm{~kg}$ の雑種成犬 4 頭 を用いた。これらのイヌに, Woodwardら (1954) の方法により, thiopental sodium の静脈麻酔下 に, innervated antral pouch (I. A.P. と略す) を 作製した. 実験には，I.A.P. 作製後 約 4 週間以 上経過し, 食慨掑取が良好で健康な状態に回復し てから使用した．実験に先だちこれら実験犬は， 前日より約 18 時間にわたり，水以外の食慨を与 えず, 空腹状態とした.

胃運動の観察法としては, バルーン法を用い た.すなわち, 容量約 $5 \mathrm{ml}$ の小バルーンを,さ きに作製した I. A.P. 内に挿入し，これに空気を 入れ, バルーン内圧が胃運動の静止期において,

100〜 $120 \mathrm{mmH}_{2} \mathrm{O}$ になるようにした. バルーン は, 接続管を用いて水マノメーターに接続し低圧 用電気圧力計に接続して, 胃収縮圧曲線を描記せ しめた. 電気圧力計の増幅度は $200 \mathrm{mmH}_{2} \mathrm{O}$ が $6 \mathrm{~mm}$ になるようにし, 記録紙の送り速度は 1 分 間 $10 \mathrm{~mm}$ とした。

胃運動の性質や变化の表現としては, 得られた 収縮圧曲線から 1 分間の平均収縮頻度ならびに収 縮波の平均収縮圧 $\left(\mathrm{mmH}_{2} \mathrm{O}\right)$ を算出して行なっ た.

実験は, 便宜上, 以下の如き 5 つの実験群に分 けて行なった。

第 1 群：モチリン単独投与時における胃運動.

使用したモチリンは矢島ら（1975）による合成 モチリンで, $1.0 \mu \mathrm{g} / \mathrm{kg} / \mathrm{hr}$. のモチリン量が, 生 理的食塩水 $60 \mathrm{~m} l$ になる如く調製し, 持続注入器

\section{実験}

空腹時に拈けるイヌ胃の運動をバルーン法によ って観察すると，バルーン装着後 15〜30 分の間， （interdigestive period）であるとか，胃液分泌作 用が殆んぞない，などの点でガストリンとの間に 相異点も少なくない，そこで著者らは，胃運動に 対するモチリンの作用を，ガストリンとの比較に おいて観察するとともに，ガストリンとの相互作 用について検討した結果, 2,3 の興味ある知見を 得たので報告する。

\section{方法}

を用いて，静脈内に投与した。

第 2 群：テトラガストリン単独投与時における 胃運動。

ガストリンとしては，合成ガストリンである Tetragastrin（ガストプシン，日本化薬）を用い， 用量を $6.0 \mu \mathrm{g} / \mathrm{kg} / \mathrm{hr}$. とした.

第 3 群：モチリン持続投与中における，ガスト リン投与時の胃運動.

モチリン $(1.0 \mu \mathrm{g} / \mathrm{kg} / \mathrm{hr}$. $)$ 持続投与 30 分後 に，テトラガストリン $(6.0 \mu \mathrm{g} / \mathrm{kg} / \mathrm{hr}$. $)$ を投与し た。

第 4 群：テトラガストリン持続投与中における モチリン投与時の胃運動.

第 3 群とは逆に, テトラガストリン $(6.0 \mu \mathrm{g} /$ $\mathrm{kg} / \mathrm{hr}$. ) の持続投与 30 分後にモチリン（1.0 $\mu \mathrm{g} / \mathrm{kg} / \mathrm{hr}$. ) を投与した.

第 5 群：モチリンおよびテトラガストリンの胃 運動に対する硫酸アトロピンの影響.

モチリン（1.0 $\mathrm{g} / \mathrm{kg} / \mathrm{hr} . ）$ およびテトラガス トリン $(6.0 \mu \mathrm{g} / \mathrm{kg} / \mathrm{hr}$.$) によってひき起された$ 胃運動に対する硫酸アトロピンの影響, ならび に, 薬物的迷走神経遮断術 (薬物的迷切と略す) 後におけるモチリンおよびテトラガストリンの胃 運動を観察した。

硫酸アトロピンの single shotの用量としては, $0.1 \mathrm{mg} / \mathrm{kg}$ を用いた. また, 薬物的迷切として は, 硫酸アトロピンの $0.1 \mathrm{mg} / \mathrm{kg}$ の single shot に 加光, $0.3 \mathrm{mg} / \mathrm{kg} / \mathrm{hr}$. の持続投与を行なった.

\section{成 績}

胃収縮波が殆んど認められない場合や，不規則な リズムと，収縮圧を示す収縮波が散発する場合と 
がみられた。従って，バルーン插入による影響お よびバルーン内圧を $100 \sim 120 \mathrm{mmH}_{2} \mathrm{O}$ に保つこ との影響は, 極めて軽微なものと考えられた.

\section{第 1 群の成績}

実験の開始時における胃の自発性収縮の有無に かかわらず，モチリンの投与によって，著明な胃 運動の亢進が認められた。すなわち, 図 $1(\mathrm{a}, \mathrm{b})$ の如く, 胃収縮頻度の増大と収縮圧の増強が著心゙ るしかった。この胃運動の克進は，モチリン投与 後 3〜5 分に出現し始め, 観察した最長 180 分の 間認められた。ささに，モチリンによって出現す る胃収縮波には，2つの特徴的な波型を区別する ことが出来た。すなわち，第 1 の波型はモチリン 投与初期に認められるもので, 胃収縮波が比較的 規則的に，しかも連続的に出現するものである. ただし，1つ1つの収縮波の強さには強弱のちが いがあり,この点は後述するテトラガストリン投 与によって起る運動様式と異っている。そこで 便宜上，この第 1 の波型を，連続的収縮（continuous contractions）と仮称する. 第 2 の波型は, モチリン投与後, 後期によく観察されるものであ る.

図 1-a モチリン単独持続投与時における 胃運動 (A 犬)

図 1-b モチリン単独持続投与時における 胃運動 (B 犬)
$\operatorname{Motilin}(1 \mu \mathrm{g} / \mathrm{kg} . / \mathrm{hr}$.

Control
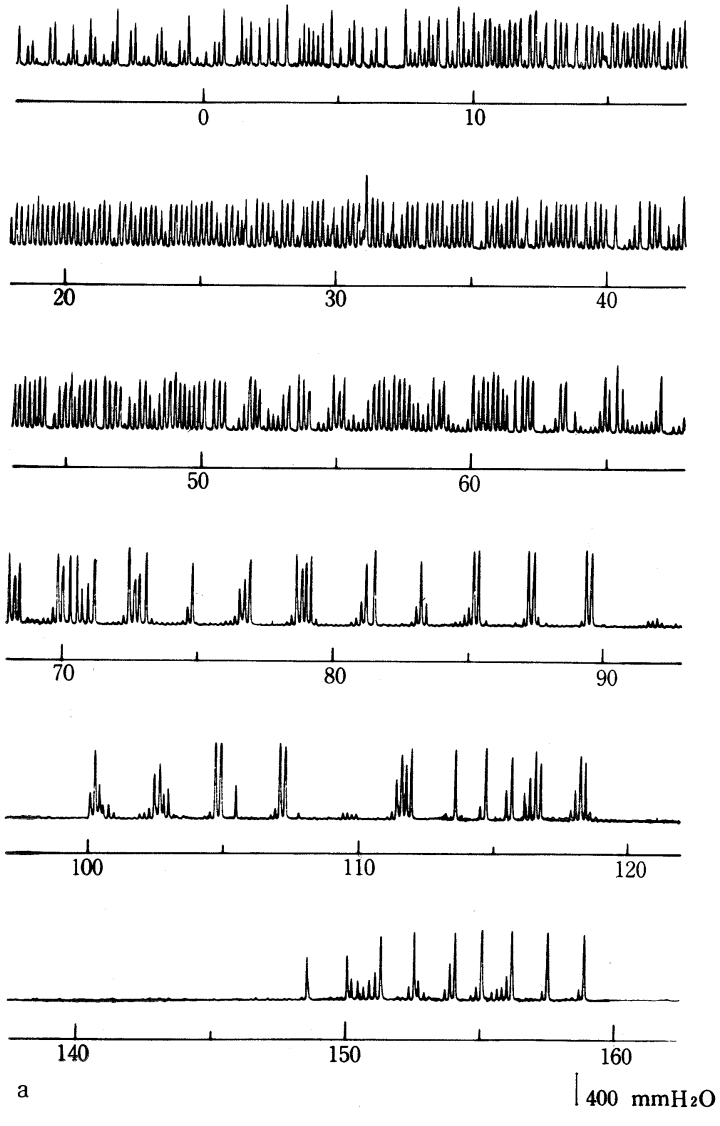
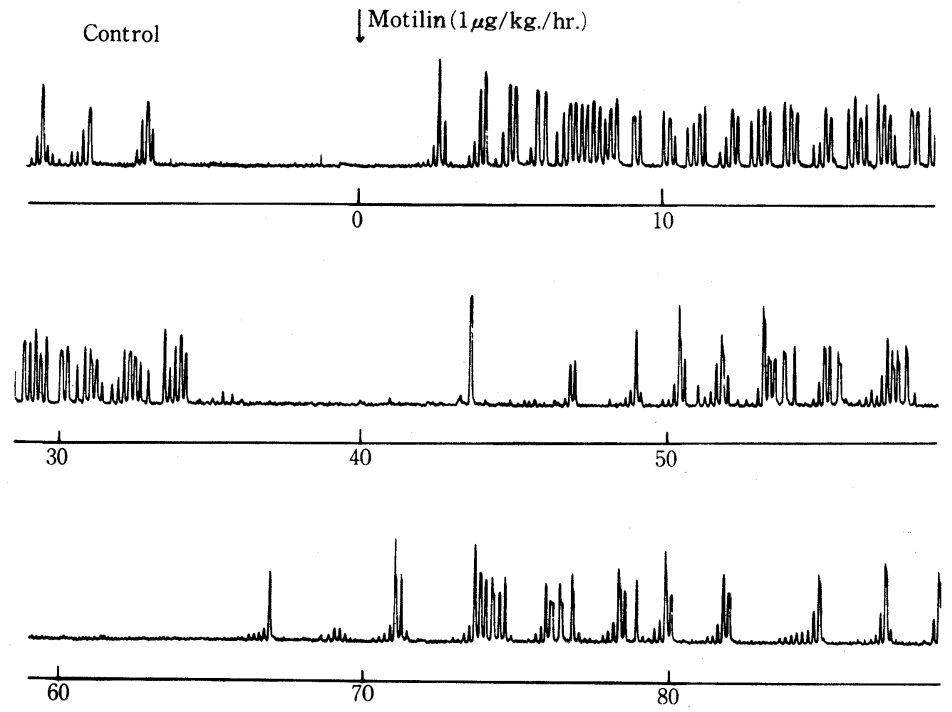
図1（a，b）にみる如く，モチリン投与後 30〜 60 分以降に認められ，ある間隔の運動休止期をも って, 胃収縮波群が間歇的に現われるものであ る.このような収縮波型の運動を, 便宜上, 間歇 的収縮（intermittent contractions）と仮称する. この間歇的収縮の特徴は, 収縮波群が, 収縮圧の 小さい収縮波から次第に大きくなり，そして再び 小さくなる山状の収縮波群を形成し，これが比較 的短い間隔でいくつかくりかえし現われ，その 後, 長い運動休止期に入ることである。この場 合, 収縮波群についてみれば, 収縮頻度は, さき の連続的収縮運動のそれとほぼ等しく, また最大 の収縮圧のみを比較するとほぼ同じであった。ま た, 運動休止期の長さには一定の周期性は認めら れなかった。

モチリン投与後の胃運動妄進は, 時間の経過と

表 1. モチリン $(1.0 \mu \mathrm{g} / \mathrm{kg} / \mathrm{hr}$. ) 持続投与特の収縮 頻度と収縮圧

Motilin $(1 \mu \mathrm{g} / \mathrm{kg}$. $/ \mathrm{hr}$.

\begin{tabular}{c|c|c|c} 
& $10 \mathrm{~min}$. & $20 \mathrm{~min}$. & $30 \mathrm{~min}$. \\
\hline $\mathrm{F}$ & $4.0 \pm 0.8$ & $4.2 \pm 0.8$ & $4.3 \pm 0.7$ \\
\hline $\mathrm{C}$ & $401 \pm 109$ & $414 \pm 115$ & $412 \pm 168$ \\
\hline
\end{tabular}

F: mean frequency per minute

$\mathrm{C}$ : mean pressure of contraction $\left(\mathrm{mmH}_{2} \mathrm{O}\right)$
ともに漸次減弱の傾向を示したが，初期において は, 表 1 の如く, 収縮力の減弱は全くなかった.

\section{第 2 群の成績}

テトラガストリン $(6.0 \mu \mathrm{g} / \mathrm{kg} / \mathrm{hr}$. $)$ 投与後にお ける定型的な胃運動曲線を図 2 に示した。すなお ち,テトラガストリン投与後 $2 \sim 3$ 分で胃収縮が 発現し, 著明な運動の充進が認められた。

テトラガストリンによってひき起される胃収縮 波は，極めて規則的かつ，高い頻度で出現するの が最も特徴的であった．収縮波は，さきのモチリ ンによる場合と異なり，各収縮波の間に大小の差 が余りないが，図 2 にみる如く，かなり急速に減 弱する傾向を示す.

すなわち，表 2 とる如く，テトラガストリ ン投与 10 分後の平均収縮圧は $333 \pm 82 \mathrm{mmH}_{2} \mathrm{O}$ であったものが, 30 分後には $196 \pm 50 \mathrm{mmH}_{2} \mathrm{O}$ と

表 2. テトラガストリン $(6 \mu \mathrm{g} / \mathrm{kg} / \mathrm{hg}$. $)$ 持続投与時 における収縮頻度と叹縮圧

Tetragastrin $(6 \mu \mathrm{g} / \mathrm{kg} . / \mathrm{hr}$.)

\begin{tabular}{c|c|c|c}
\hline & $10 \mathrm{~min}$. & $20 \mathrm{~min}$. & $30 \mathrm{~min}$. \\
\hline $\mathrm{F}$ & $6.0 \pm 0.3$ & $6.2 \pm 0.1$ & $6.1 \pm 0.2$ \\
\hline $\mathrm{C}$ & $333 \pm 82$ & $236 \pm 71$ & $196 \pm 50$ \\
\hline
\end{tabular}

$\mathrm{F}$ : mean frequency per minute

$\mathrm{C}$ : mean pressure of contraction $\left(\mathrm{mmH}_{2} \mathrm{O}\right)$
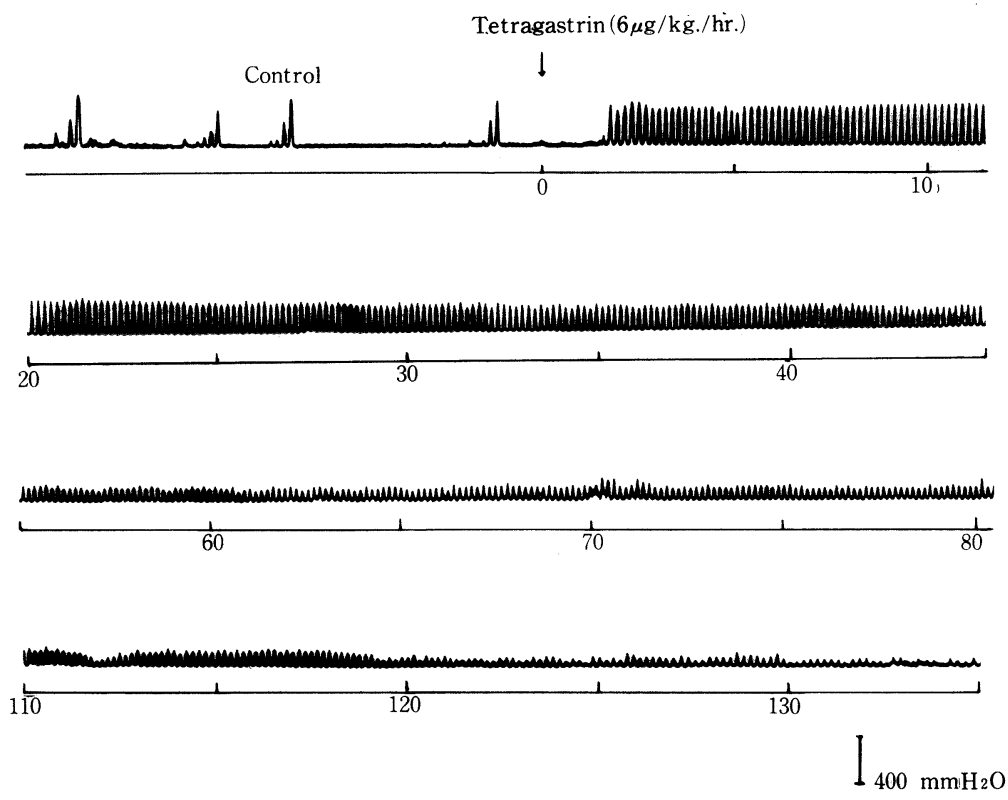

図 2. テトラガストリン単独持続投与時における胃運動 


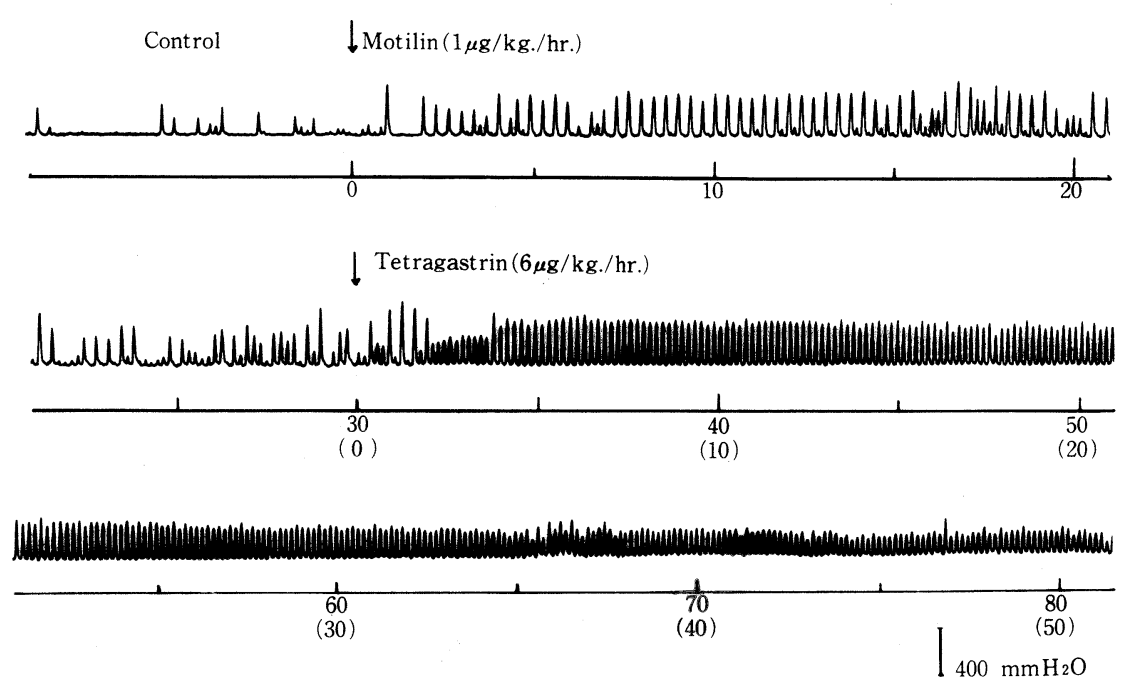

図 3-a，モチリン持続投与後，テトラガストリン追加投与時の胃運動

なっている. 一方, 平均収縮頻度は 10 分後 $6.0 \pm$ $0.3,30$ 分後 $6.1 \pm 0.2$ と殆んど変化を示していな w.

\section{第 3 群の成績}

モチリン（1.0 $\mu \mathrm{g} / \mathrm{kg} / \mathrm{hr} . ）$ の持続投与 30 分後 にテトラガストリン $(6.0 \mu \mathrm{g} / \mathrm{kg} / \mathrm{hr}$. ) を新たに持 続投与すると，図 3-a の如く，それまでのモチリ ンによる先述した continuous contractions は,さ らに収縮頻度を增すとともに，不揃だった収縮圧 も比較的等しくなって運動の著明な立進を示し た。

本実験による平均収縮頻度ならびに収縮圧は, 表 3 の如くであり，テトラガストリンを加えるこ とによって，平均収縮頻度は毎分 $4.5 \pm 0.6$ から
表 3.モチリン投与後，テトラガストリン追加投与時 の収縮頻度と収縮圧

1- Motilin (1 $\mu \mathrm{g} / \mathrm{kg}$. $/ \mathrm{hr}$.) $1-$ Tetragastrin $(6 \mu \mathrm{g} / \mathrm{kg} . / \mathrm{hr}.) \longrightarrow$

\begin{tabular}{|c|c|c|c|c|c|c|}
\hline & $10 \mathrm{~min}$ & $20 \mathrm{~min}$. & $30 \mathrm{~min}$. & $10 \mathrm{~min}$. & $20 \mathrm{~min}$ & $30 \mathrm{~min}$. \\
\hline $\mathrm{F}$ & $4.0 \pm 0.4$ & $5 \pm 0$ & $4.5 \pm 0$ & 7 & & 3 \\
\hline C & 428 & 20 & $429 \pm$ & & & $=114$ \\
\hline
\end{tabular}

F: mean frequency per minute

$\mathrm{C}$ : mean pressure of contraction $\left(\mathrm{mmH}_{2} \mathrm{O}\right)$

$5.7 \pm 0.2 \sim 6.1 \pm 0.3$ 亿増大している. 平均収縮 圧は, テトラガストリン投与後 10 分では $426 \pm$ $100 \mathrm{mmH}_{2} \mathrm{O}$ と殆んど変化はないが， 30 分後には $290 \pm 114 \mathrm{mmH}_{2} \mathrm{O}$ と低下している.

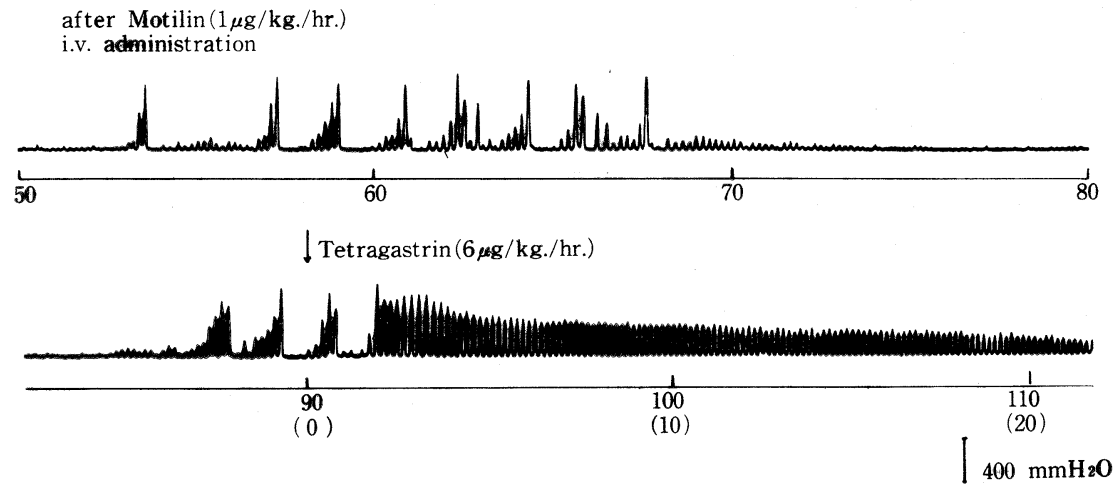

図 3-b. モチリン持続投与後, テトラカストリリン追加投与時の胃運動 
テトラガストリンの投与によって, 第 1 群の実 験で認められた如き，モチリンによる intermittent contractions は，その発現をみなくなった。 一方, 図 3-bに示寸如 $<$, intermittent contractions は，テトラガストリン投与によって波型が 変化し, 収縮頻度を増すとともに, 収縮圧は漸減 した.

しかし，収縮圧の減弱は，ガストリン単独の場 合に比し，その程度は一層緩徐であった。

\section{第 4 群の成績}

テトラガストリン $(6.0 \mu \mathrm{g} / \mathrm{kg} / \mathrm{hr}$. $)$ の持続投与 開始 30 分後に, モチリン $(1.0 \mu \mathrm{g} / \mathrm{kg} / \mathrm{hr}$. ) を持 続投与した際の胃収縮圧曲線を図 4 に示した。収 縮頻度は, モチリンの追加投与によっても変化を 認めなかったが，収縮圧は軽度增大した。すなわ ち, 表 4 に示す如く, テトラガストリン投与 30 分 後の平均収縮頻度は毎分 $6.1 \pm 0.3$, 平均収縮圧は $181 \pm 78 \mathrm{mmH}_{2} \mathrm{O}$ であったが，モチリン投与 10 分 後で, すでに平均収縮圧は, $326 \pm 163 \mathrm{mmH}_{2} \mathrm{O}$ と 増強されており, 30 分後には, $352 \pm 120 \mathrm{mmH}_{2} \mathrm{O}$ とテトラガストリン投与後 10 分におけるとほぼ 同程度にまで増強された。しかし，この増強され た収縮圧も時間の経過とともに減弱した。すなわ ち，テトラガストリンの単独投与では, 収縮頻 度は不変で, 収縮圧が急速に減弱するのに，モチ
表 4. テトラガストリン投与後モチリン追加投与時の 収縮頻度と収縮圧

I—— Tetragastrin $(6 \mu \mathrm{g} / \mathrm{kg} . / \mathrm{hr}$. 1- Motilin $(1 \mu \mathrm{g} / \mathrm{kg} . / \mathrm{hr}$.)

$10 \mathrm{~min} .|20 \mathrm{~min}| .30 \mathrm{~min} .|10 \mathrm{~min}| .20 \mathrm{~min} . \mid 30 \mathrm{~min}$.

F $6.1 \pm 0.36 .1 \pm 0.56 .1 \pm 0.36 .2 \pm 0.36 .0 \pm 0.46 .1 \pm 0.3$

C $365 \pm 90|244 \pm 120| 181 \pm 78|326 \pm 163| 351 \pm 110 \mid 352 \pm 120$

$\mathrm{F}$ : mean frequency per minute

$\mathrm{C}$ : mean pressure of contraction $\left(\mathrm{mmH}_{2} \mathrm{O}\right)$

リンが加えられたことで, 収縮圧の減弱傾向が弱 まる結果を示した。つまり，テトラガストリンと モチリンの共存下では, 収縮頻度ではガストリン が，また収縮圧においてはモチリンが，それぞれ 優位を保ち，相互に運動の減弱を阻止する如き作 用を示した。

\section{第 5 群の成績}

モチリン $(1.0 \mu \mathrm{g} / \mathrm{kg} / \mathrm{hr}$. $)$ およびテトラガスト リン $(6.0 \mu \mathrm{g} / \mathrm{kg} / \mathrm{hr}$. ) の持続投与によってひき 起された胃運動に対する硫酸アトロピン $(0.1 \mathrm{mg} /$ $\mathrm{kg})$ の急速投与の影響は図 $5(\mathrm{a}, \mathrm{b})$ の如くであっ た。すなわち，モチリンでは，硫酸アトロピンの 投与によって急速, かつ完全に胃収縮運動の消失 を認めた，一方，テトラガストリンでは，著明な る減弱を示すものの, 完全なる胃運動の消失は認
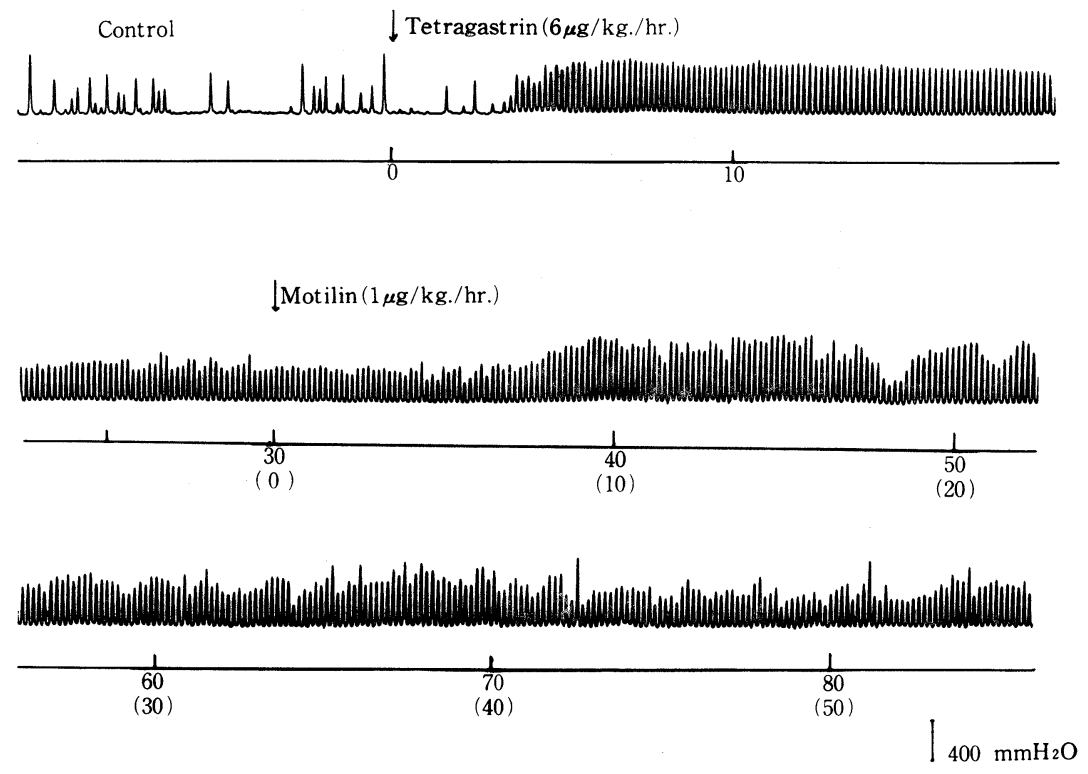

因 4.テトラガストリン投与後，モチリン追加投与時の胃運動 

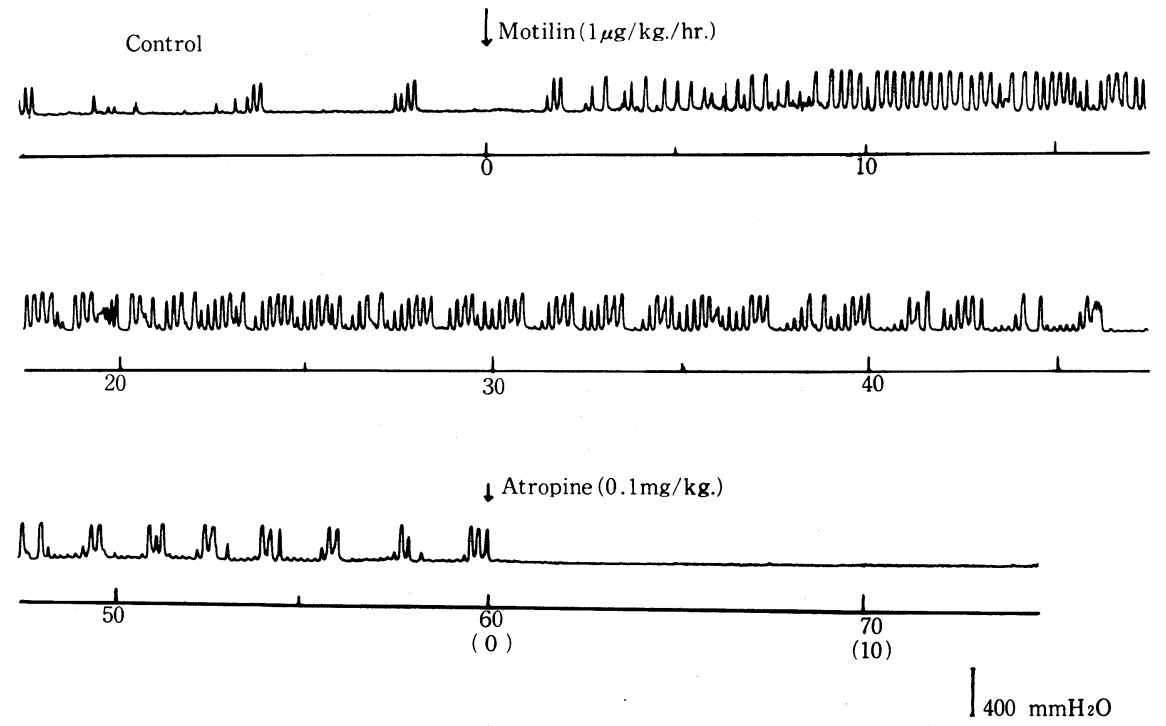

図 5-a、モチリン投与後, 硫酸アトロピン急速投与時の胃運動

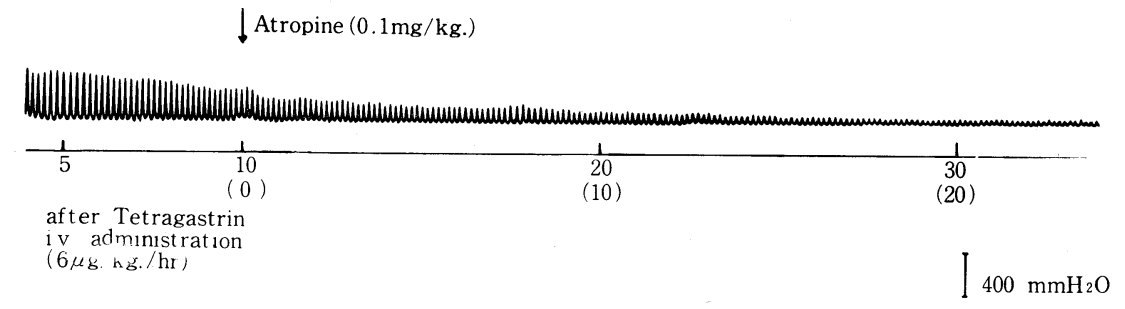

囝 5-b. テトラガストリン投年後, 硫酸アトロピン急速投与時の胃運動
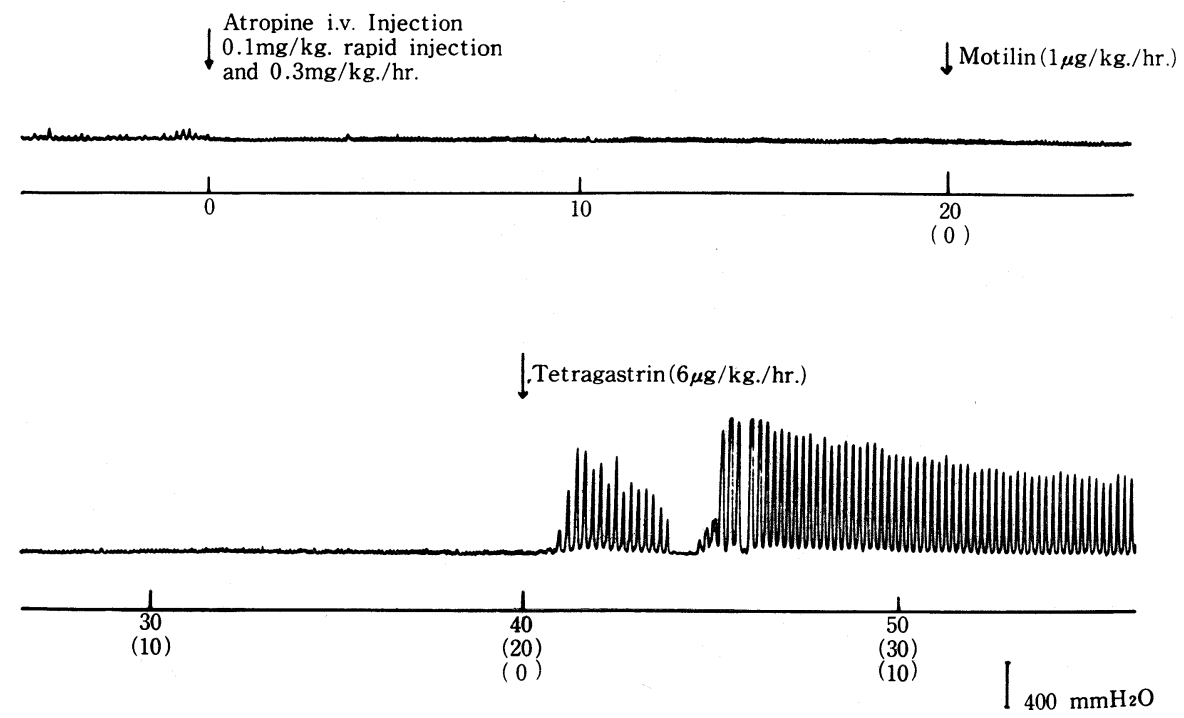

図 6. 迷切下におけるモチリンおよびテトラガストリン投与時の胃運動 
められなかった。

薬物的迷切としては, 硫酸アトロピン $(0.1 \mathrm{mg} /$ $\mathrm{kg}$ ）の急速静脈内投与に加光， $0.3 \mathrm{mg} / \mathrm{kg} / \mathrm{hr}$.）の 持続投与を行なった。 この量の硫酸アトロピンで は, 胃における自発性収縮を, 直ちに, 完全に消 失せしめるのみならず，インスリン刺激や，胃拡 張刺激によってひき起された強力な胃収縮をも， 完全に消失せしめた，従ってこの量をもって，薬

\section{考}

空腹時に十二指腸内をアルカリ性にすることに よって, 胃運動が誘発ないし立進されるといら Brown ら（1966）の実験は, 結局, 消化管ホルモ ンの1つであるモチリンの発見（Brown 1967）と なったわけである。空腹時における胃, 腸管の強 い運動, つまり, 飢餓収縮の存在 (Carlson 1914, Hoelzel 1925）は，以前より観察されていたので あるが，最近になって，乙のモチリンが，いわゆ る hunger contractionの刺激原であろらとの説が かなり有力になってきている. Code ら（1975）, 伊藤ら (1977)，相沢ら（1977）は，消化管に拈 ける interdigestive contractions の発生機構を説 明するのに，モチリンが極めて好都合なものと考 えている，その後，合成モチリンの開発（Brown 1967, Yajima ら 1975, Kai ら 1975）によって, 種々の生理学的, 薬理学的実験がなされている が，これまでの所，モチリンの胃腸管に対する生 理的作用や意義について，必ずしも明確な結論が 得られているわけではない。モチリンの胃運動 に対する作用についても，収縮運動の発現様式 や，他の消化管ホルモンとの相互作用についての 報告は極めて少ない，そこで，著者らは，モチリ ンによる胃運動の収縮パターンおよび，同じく胃 運動刺激作用のあるガストリンの胃運動作用との 比較, さらに，ガストリンの相互作用について検 討を加えよらと試みたわけである。

合成モチリンによってひき起こされた胃収縮運 動のパターンには, すでに述べた如く, その発現

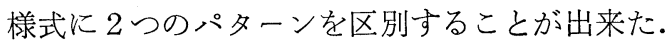

1 つには，モチリン投与初期に認められるもの で, 収縮頻度も比較的大きく, 律動的 (rhythmic) で，休止期をもたない，持続性のある収縮波群で ある。その点では，テトラガストリン投与時のむ のとかなり似たものであるが，個々の収縮波の高
物的迷切とみなした。

以上の如き薬物的迷切下に, モチリン $(1.0 \mu \mathrm{g} /$ $\mathrm{kg} / \mathrm{hr}$. ) を投与すると, 図 6 に示す如く，モチリ ンは胃運動をおこし得なかった。

しかし，テトラガストリンは，同じく図6にみ る如く, 明らかに強力なる胃運動を誘発せしめ た。

\section{案}

さ，つまり，個々の蠕動収縮の収縮力に差があっ て，不揃であることが 1 つ大大な相異点であっ た。 また, ガストリンの場合には, 投与後, 時間 の経過とともに，かなり急速に収縮力が減弱して ゆくのに反し，モチリンでは長時間にわたって， 強い収縮を持続する特徵が認められた。他のもう 1つの収縮パターンは，モチリン投与後後期に認 められるもので, 先に述べた如く, いわゆる intermittent contractions である.この収縮パター ンは, ガストリン投与では認められないものであ る。

このパターンにおける, 収縮波群の出現する収 縮期と，全く運動を認めない休止期が，交互に現 われる特徴は, 伊藤ら（1977）のいら interdigestive contraction と intermediate state にかなり類 似性をもっていると考兄られるが, 収縮の持続時 間や，休止期の長さに，大きな開きがあること， しかも, 規則性がないなどの点で異なっているよ らに思われる。

先に述ベた運動様式の第 1 のパターンから第 2 のパターンへの移行は, 別に行なったモチリンの $0.5 \sim 1.5 \mu \mathrm{g} / \mathrm{kg} / \mathrm{hr}$. の用量の同様の実験でも殆ん ど無関係に認められており, 一方, 第 2 のパター ンから第1のパターンへの移行は認められなかっ た，そして，第 2 のパターンで胃運動で起ってい るときにガストリンを加えると, 再び第 1 のパタ ーンに移行した如き収縮パターンを示すが，しか し, この变化は, 収縮頻度の増加および収縮圧の 低下などガストリン固有の変化であることから， ガストリンによる作用と考光られる。いづれにし

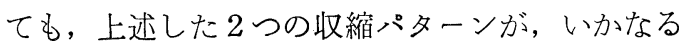
理由によって出現してくるものかについては不明 である。

ガストリンの胃運動作用については, 多くの報 
告 (Gregory $ら$, Blair $ら$, Abott $ら$, Bennet $ら$, Smith $ら$, Misiewicz $ら$, Jacoby $ら$, Eisenberg $ら$, Sugawara ら, 長尾ら, 沖田, 真部) があり, その 結論も，ほ汪一定している。すなわち，胃運動の 六進である.この場合の胃運動の亢進について多 少問題があるのは, 運動立進が, 収縮頻度の増大 なのか, 収縮力の增強なのか, あるいは, その双 方によるものであるかといら点であって，この点 については研究者によって少しく見解を異にして いる. 確かに，ガストリン投与直後，とりわ将 速静注後の胃運動についてみると, 注射直後に極 めて収縮の強い, 頻度の高い運動がみられる。乙 かし，持続投与により比較的長時間にわたって観 察してみると，さきの如き強い収縮運動は，ガス トリン投与直後の短時間だけに認められるもので あって, 多くの場合は 20〜30 分も経過すると, か なり急速に収縮力は減弱するものである。この場 合にも, 収縮頻度は長時間にわたって殆んど変ら ない. 菅原ら（1969）および沖田（1976）は，ガ ストリンの胃運動に対する主たる作用は, 収縮頻 度をたかめることであって，収縮力はむしろ低下 させることを述べている，つまり，胃運動が弱い 場合には増強させるが，強い収縮に対してはこれ を抑制するものである事を述べている。

このような事は, 相沢ら（1976）によっても観 察されており，ガストリンに胃運動抑制作用のあ ることを述べている。相沢らの場合でも, ガスト リン投与前の胃運動は, interdigestive contractions で, 胃運動の強い状態でガストリンが投与されて いることから，この抑制作用というのも，結局の とてろ，菅原らや沖田の報告と範を一にしている ものと考党られる。

さてひぎに，モチリンとガストリンの相互作 用についてみてみると，モチリン投与によって， さきに述べた如き初期の収縮パターン (continuous contractions）が出ている時にガストリンを投与す ると, 収縮頻度はガストリン単独投与時のそれと ほぼ等しくなると同時に, 収縮圧は減弱の傾向を 示す.

しかし, この場合の収縮圧減弱の傾向は, ガス トリン単独投与時のそれと比較して小さく, モチ リンによる収縮力増強作用が, ガストリンの共存 下でも発揮されていることが推定された。モチリ ン投与後期に認められる第 2 のパターン (inter- mittent contractions）の認められるときに，ガス トリンを投与した場合には, 図 3-bにみた如く, それまでの収縮パターンは消失し，注ぼガストリ ン投与時のものになり，ガストリン投与前のパタ ーンには復しなかった。

つぎに，さきとは逆に，ガストリン投与後にモ チリンを投与した場合は, 収縮頻度はひきつづき 同じ值を示し，収縮圧は一時的に增大する傾向を 示し，それから次第に減弱していった．以上のこ とから，モチリンおよびガストリンの共存下にお ける相互作用をみてみると，収縮頻度において は, 常にガストリンが, 収縮圧に执いてはモチリ ンが優位に作用していることが推定される。一 方, 伊藤ら（1977）は, intermediate state に合成 モチリンを投与することによって，常に interdigestive contractions と極めてよく似た胃運動が 惹起されるが, digestive state, すなわち, feeding 後に合成モチリンを投与しても，何ら变化を認め なかったと報留している，著者らのモチリン投与 実験は, feeding 後ではなく, 外因性ガストリン の投与下であるといら実験条件が異なるので，同 じに論ずることは出来ないが, 著者らの, 先の実 験結果からこの点を推論してみると，ガストリン 持続投与中に拈けるモチリン投与では, 収縮頻度 の上では，モチリンの効果は表現されず，また， 収縮力については, 食後の胃収縮は, 単にガスト リンのみに因らず，食物による拡張刺激や，中枢 性の刺激によって, ある程度強さを有していると 考光られるから，モチリンの収縮力増強作用は必 ずしも示されないと考光られる。

結局, モチリンの運動作用が, digestive state の運動の中に包含されているとも考えられるわけ である。

モチリンおよびガストリンが, 副交感神経遮断 凨である硫酸アトロピンの影響をどのように受け るかについて, 著者らは, 硫酸アトロピンの急速 静注と,アトロピンによる薬物的迷切といら $2 つ$ の条件下に実験を行なったわけである。ところ が，モチリンによってひき起された強力な収縮運 動は, 硫酸アトロピンによって, 全く完全に消失 し, また薬物的迷切下では運動の出現が完全に阻 止された。

しかるに，ガストリンによって刺激された胃運 動は, 硫酸アトロピンによって, かなり抑制され 
るものの, 収縮運動の完全な消失をみることはな く, また薬物的迷切下においては, 運動の出現が 全く阻止されなかった。

このように, モチリンが, 副交感神経遮断剤の

\section{結}

Innervated Antral Pouch を作製した 4 頭のイ ヌを用いて, バルーン法によって，合成モチリン の胃運動に及ぼす作用を観察した。 また，ガスト リンとの相互作用ならびに, 硫酸アトロピンの影 響についても検討し, 次の如き結果を得た.

1. 空腹時におけるモチリンの投与によって胃 の運動は著明に六進した。

2. モチリン投与によって出現する胃運動の収

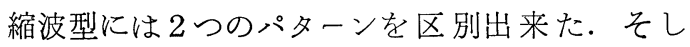
て，そのいづれもがガストリン投与によってひき 起される収縮パターンとは異なるものであった。

3.モチリンによる胃運動の立進は, ガストリ ンに比し, 収縮頻度において小さく, 収縮力にお いて大きかった。

4. モチリンによってひき起された胃運動は, ガストリンによるそれと異なり，時間経過による 減弱の傾向が小さかった。

5. モチリン持続投与にひきつづき，ガストリ ンを持続投与した場合には, 収縮頻度はガストリ ン固有の大きい值に变化した。一方, 収縮圧は漸 減するものの, ガストリン単独投与の場合に比し 小さかった。
影響を極めて強く受けることは，ガストリンと異 なる大きな相異点の1つであるが，その理由につ いては不明である。

\section{語}

6. ガストリン持続投与に加えてモチリンを持 続投与した場合には, 収縮頻度には変化はなく, 収縮圧は軽度の增強が認められた。

7.つまり，モチリンとガストリンの共存下に おいては, 収縮頻度においては, ガストリンが, また，収縮圧に扔いてはモチリンのもつ作用が優 位に表現された。

8. モチリンおよびガストリンの持続投与時に 硫酸アトロピンを急速投与すると，モチリンによ る胃運動は, 直ちに, 完全に消失したが, ガスト リンでは, 運動の減弱を認めるものの, 完全なる 消失は認められなかった。

9. 薬物的迷切下における，ガストリン投与で は，強い運動の発現をみたが，モチリンでは全く 認められなかった。

以上の実験結果から，モチリンは，胃運動の強 力な刺激源であるが，ガストリンとは多くの点で 相異点を有している事が知られた。

稿を終るにあたり，本研究のために貴重なる合成モチリ ンを提供して下さった京都大学薬学部 矢島治明教授に深 甚の謝意を表します.

\section{文献}

Abott, D.D. et al. (1965). Relationship of antral motility to gastrin activity in surgically prepared dogs. J. Pharm. Sci. 54: 1713-1718.

相澤＼cjkstart勇他 (1976). 消化管運動に対するガストリンの抑制作用. 日平滑筋誌. 12: 283-284.

相沢＼cjkstart勇他 (1977). イヌにおける血中 motilin の変動と胃運動. 日消会誌. 74: 1166-1171.

Bennet, A. (1965). Effect of gastrin on isolated smooth muscle preparations. Nature 208: 170173.

Bennet, A. et al. (1967). Analysis of the motor effects of gastrin and pentagastrin on the human alimentary tract in vitro. Gut 8: 470-474.

Blair, E.L. et al. (1961). A simple method of preparing gastrin. J. Physlol. (London) 156: 11-13.

Blair, E.L. et al. (1963). Characteristics of responses to gastrin extracts. J. Physiol. (London) 165: $81-82$.

Brown, J.C. et al. (1966). Effect of duodenal alkalinization on gastric motility. Gastroenterology 50: 333-339.

Brown, J.C. (1967). Presence of a gastrin motor stimulating property in duodenal extracts. Gastroenterology 52: 225-229. 
Carlson, A.J. et al. (1914). Contributions to the physiology of the stomach. Am. J. Physiol. 33: 119125 .

Code, C.F. et al. (1975). The interdigestive myoelectric complex of the stomach and small bowel of dogs. J. Physiol. 246: 289-309.

Edkins, J.S. (1906). The chemical mechanism of gastric secretion. J. Physiol. (London) 34: $133-144$.

Eisenberg, J.I. and Grossmann, M.I. (1969). Effect of gastrin and SC 15396 on gastric motility in dogs. Gastroenterology 56: 450-455.

Gregory, R.A. and Tracy H.J. (1964). Physiological properties of series of synthetic peptides structurally related to gastrin I. Nature 204: 935-938.

Gregory, R.A. et al. (1964). The constitution and properties of two gastrin extracted from hog antral mucosa. Gut 5: 103-117.

Hoolzel, F. (1925). The relation between the secretory and motor activity in the fasting stomach (man). Am. J. Physiol. 73: 463-469.

伊藤 漸他 (1977)，合成 motilin の胃運動に対する作用一意識下のイヌにおける研究. 日消会誌. 72：155163.

Jacoby, H.I., and Marschall, C.H. (1969). Gastric motor-stimulating activity of gastrin tetrapeptide in dogs. Gastroenterology 56: 80-87.

Kai, Y. et al. (1975). Studies on peptides: L.V. Total synthesis of porcine motilin, a gastric motor activity stimulating polypeptide. Chem. Pharm. Bull. 23: 2346.

長尾房大，田中直樹，青木照明（1970）。胃筋電図と胃液分泌。日本臨㕅，28：2412-2418.

兵部光正 (1977)。カカストリンの胃運動作用（とくに薬物的迷切下において）。 日平滑筋誌. 13: 260-262.

Misiewicz, S.L. (1967) Motor responses of the human alimentary tract to nearmaximal infusion of pentagastrin. Gut 8: 463-469.

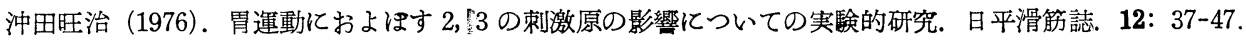

Shimizu, F. et al. (1976). Synthesis of poroine motilin by fragment condensation using three protected peptide fragment. Bull. Chem. Soc. Jap. 49: 3594-3596.

Smith, A.N. and Hogg, D. (1966). Effect of gastrin II on the mofility of the gastrointestinal tract. Lancet. 1 : 403-404.

Sugawara, K. Isaza, J. and Woodward, E.R. (1969). Effect of gastrin on gastric motor activity. Gastroenterology 57 : 649-658.

Sugawara, K. et al. (1970). The Effect of pentagastrin on gastric motility following vagotomy. J. Surg. Res. 10: 73-80.

Sugawara, K., Chawla, R.C. and Eisenberg, M.M. (1973). Rhythmic contractility of the canine stomach; variation and anatomic relationship. Proc. Soc. Exp. Biol. 142: 896-901.

Woodward, E.R, et al. (1954) The Physiology of the gastric antrum pouches in dogs. Gastroentepology 27: 766-785.

Yajima, H. et al. (1975). Synthesis of the docosapeptide corresponding to the entire amino acid sequence of porcine motilin. J.C.S. chem. Coom. P. 159.

(1978年 5 月 8 日受付) 